\title{
RECENT EVOLUTION OF THE CAPITAL MARKETS IN ROMANIA
}

\author{
Catalin Drob \\ "Vasile Alecsandri” University of Bacau \\ catad@ub.ro
}

\begin{abstract}
The purpose of this study is to emphasize the main aspects regarding the establishment, development and evolution of the capital market in Romania. This study tries to present the main milestones which marked the evolution of the national capital market from the beginning until now. Even if the first Romanian stock exchange was established in 1881, the modern capital market in Romania is a relatively young, which began to function with the reestablishment of Bucharest Stock Exchange in 1995. The capital market in Romania has a great potential of development. Statistical data presented in this paper, regarding the evolution and the development of the capital market in Romania, emphasizes that this market was and is strongly linked to developments in the real economy.
\end{abstract}

\section{Keywords}

economy; realities; crisis; capital market; growth; Romania

\section{JEL Classification}

D53; E44

\section{Introduction}

The capital market is a specialized market where meets the supply and the demand for financial assets on medium and long term. On this market are freely traded securities such as shares, bonds and derivatives. This market has the leading role in raising capital; these funds are attracted by the issuers of shares / bonds who are seeking capital to finance investment projects.

The capital market has two components:

- Primary market - is the market where new issues of securities are negotiated for the first time. It is about the process by which financial intermediaries place newly issued securities in exchange for a fee;

- Secondary market: once securities are put in circulation in the primary market, they are subject to secondary market transactions. The effective functioning of the secondary market is realized through negotiations markets or through organized markets such as the Stock Exchange and the OTC (Over The Counter) markets.

Between the two forms of capital market (stock exchange and OTC) there are several differences such as:

- the stock exchange is very centralized while the OTC market is less centralized;

- the stock exchange is very regulated while the OTC market is less regulated;

- the stock exchange ensures transaction security, while the OTC markets provides a lower level of transaction security.

- the stock exchange is an auction market while OTC is a negotiation market etc. 


\section{The evolution of the capital market in Romania}

As stated by Dragotă, V et al (2009), historically and economically, Romania evolved inconstantly over time. In Romania, the capital market formation was related to the appearance in Bucharest in 1881, of the first stock exchange and of the adoption of the first laws that regulate the functioning of this capital market. Further development of the Romanian capital market was favored by improving the legislative framework in 1904 and 1929 and by the development of the capitalism system. The evolution of the capital market in Romania by the end of the World War II was heavily influenced by major events that occurred during that period (Romania's participation at the two world wars, the economic crisis of 1929-1933, etc.). During this period, the best results of the Bucharest Stock Exchange were recorded in 1939.

The change of political regime in Romania after the conclusion of World War II meant the end of the capital market and stock market amid the start of the process of nationalization of the national economy and instauration of state property.

After 1989, with the restoration of market economy in Romania it was also necessary the reestablishment the capital market and its specific institutions. Thus, in 1995 occurs the reestablishment of BSE (Bucharest Stock Exchange). The first trading session at the BSE had took place on 20 November 1995.

The Stock Market in Romania was structured, since the beginning, on two distinct components: Bucharest Stock Exchange (BSE) and Romanian Association of Securities Dealers Automated Quotation (RASDAQ), which subsequently merged into a single market, by absorbing RASDAQ by BSE. Bucharest Stock Exchange started work in 1995 while RASDAQ began operating in 1996. The two markets have had a similar evolution, influenced by economic and political developments in Romania.

In regards to the Bucharest Stock Exchange, the listing of a derivative to this stock exchange can be done on two sections: national or international. The national section of BSE is divided into three categories: I, II and III. Inclusion in a given category is made according to the degree of compliance with the economic performance criteria, inclusion in first category requiring the fulfillment of additional criteria such as a profitable activity in the past two years.

RASDAQ market consists of three categories of issuers, divided in three categories, depending on certain criteria of performance and liquidity:

- the first category of excellence;

- category II of excellence;

- category III (Basic).

The functioning of the capital market and of the stock exchange in our country was regulated primarily by the Law 52/1994 regarding securities and stock exchanges and by the law 297/2004 which aimed at strengthening the existing legislation at that time in the field of capital market and adapt it to the provisions of Community legislation. In present, the administration, implementation, and monitoring and compliance with the provisions of these laws is carried out by the Financial Supervisory Authority.

With regard to the performance of the Bucharest Stock Exchange, we can say that after a very good start, with a maximum of traded securities and of stock values recorded in 1997, followed a major decline, until the end of the year 2000. Starting with 2001, the evolution of the stock market was a positive one until the commencement of economic and financial crisis in 2008. The year 2008 was a very difficult year for the stock market in Romania. This year, the index of the Bucharest Stock Exchange lost 70,5\% of its value recorded in 2007.

The stock market recorded a comeback in 2009, a decline in 2011, a stagnation in 2012 and a slight increase in 2013. With regard of shares traded on the BSE, after strong rebound recorded on the market in 2008 and 2009, the value of transactions 
with shares had a positive trend starting with 2010 (a value of transactions with shares of 2.5 billion euros in 2013, compared to only 1.3 billion in 2010).

In 2013, the stock capitalization of BSE recorded a value of around 30 billion Euros, of which 11.3 billion Euros represents only the capitalization of Erste Bank Group, which is the largest company listed on the BSE. The evolution of the value of transactions and of stock market capitalization at BSE from 2001 to 2013 is presented in the following table and figure:

Table1 The evolution of the value of transactions and of stock market capitalization at BSE

\begin{tabular}{|c|c|c|c|c|c|c|c|c|c|c|c|c|c|}
\hline Year & $\mathbf{2 0 0 1}$ & $\mathbf{2 0 0 2}$ & $\mathbf{2 0 0 3}$ & $\mathbf{2 0 0 4}$ & $\mathbf{2 0 0 5}$ & $\mathbf{2 0 0 6}$ & $\mathbf{2 0 0 7}$ & $\mathbf{2 0 0 8}$ & $\mathbf{2 0 0 9}$ & $\mathbf{2 0 1 0}$ & $\mathbf{2 0 1 1}$ & $\mathbf{2 0 1 2}$ & $\mathbf{2 0 1 3}$ \\
\hline $\begin{array}{c}\text { Transactions } \\
\text { value } \\
\text { (billion Euros) }\end{array}$ & 0,1 & 0,2 & 0,3 & 0,6 & 2,2 & 2,8 & 4,2 & 1,9 & 1,2 & 1,3 & 2,3 & 1,7 & 2,5 \\
\hline $\begin{array}{c}\text { Stock Market } \\
\text { capitalization } \\
\text { (billion Euros) }\end{array}$ & 1,4 & 2,6 & 3,0 & 8,8 & 15,3 & 21,4 & 24,6 & 11,6 & 19,1 & 23,9 & 16,4 & 22,1 & 30 \\
\hline
\end{tabular}

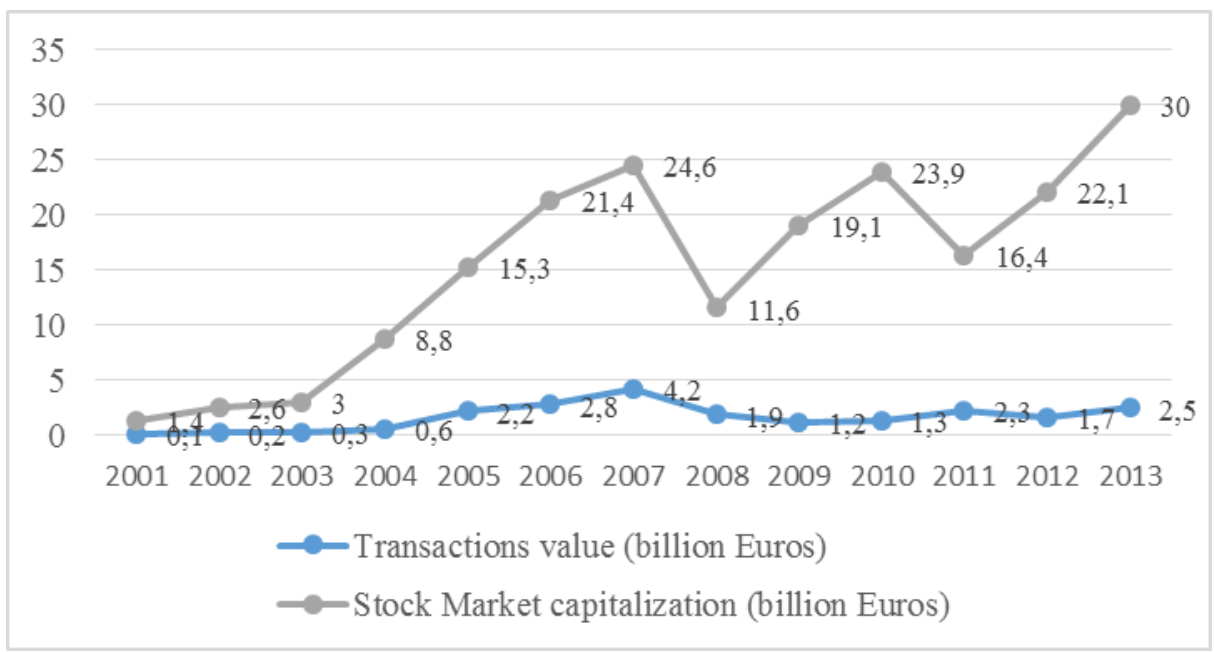

Figure 1 The evolution of the value of transactions and of stock market capitalization at BSE

Regarding the number of companies traded on the BSE in 2013 situation is as follows:

- the international section: 1 company (Erste Bank Group);

- the national section:

- $\quad$ category I: 28 companies;

- category II: 52 companies;

- $\quad$ category III: 1 company.

On RASDAQ market, the value of transactions with shares is much smaller than the amount of transactions with shares at BSE. Starting with 2008, the market value of transactions with shares had a negative evolution, recording only in 2013 a slight increase in relation to the year 2012.

The evolution of the value of transactions on RASDAQ market from 2001 to 2013 is presented in the following table and figure: 
Table 2 The evolution of the value of transactions on RASDAQ market

\begin{tabular}{|c|c|c|c|c|c|c|c|c|c|c|c|c|c|}
\hline Year & $\mathbf{2 0 0 1}$ & $\mathbf{2 0 0 2}$ & $\mathbf{2 0 0 3}$ & $\mathbf{2 0 0 4}$ & $\mathbf{2 0 0 5}$ & $\mathbf{2 0 0 6}$ & $\mathbf{2 0 0 7}$ & $\mathbf{2 0 0 8}$ & $\mathbf{2 0 0 9}$ & $\mathbf{2 0 1 0}$ & $\mathbf{2 0 1 1}$ & $\mathbf{2 0 1 2}$ & $\mathbf{2 0 1 3}$ \\
\hline $\begin{array}{c}\text { Transactions value } \\
\text { (billion Euros) }\end{array}$ & 0,1 & 0,13 & 0,11 & 0,15 & 0,3 & 0,24 & 1,3 & 0,43 & 0,14 & 0,14 & 0,14 & 0,05 & 0,07 \\
\hline
\end{tabular}

\section{Transactions value (billion Euros)}

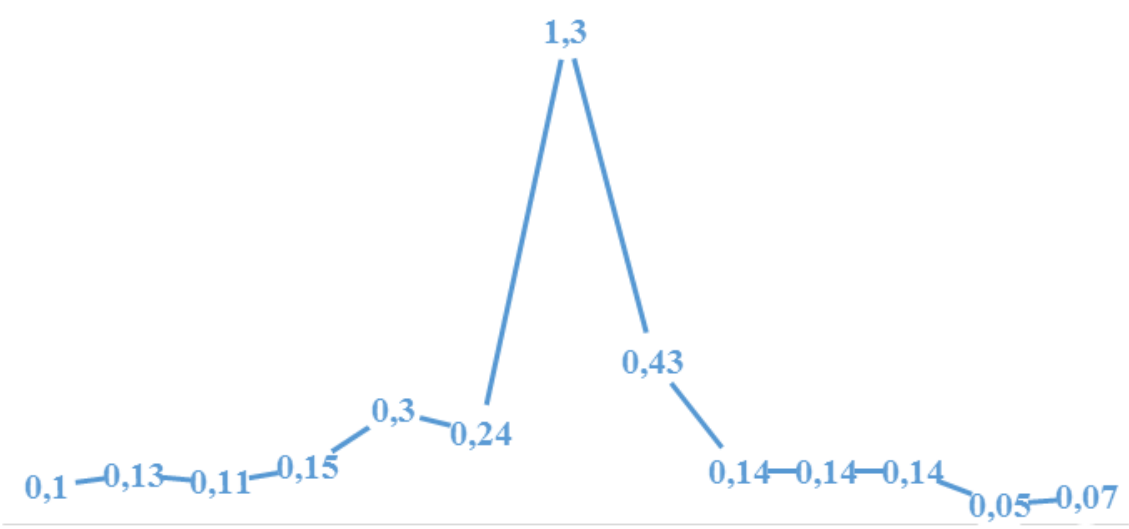

2001200220032004200520062007200820092010201120122013

Figure 2 The evolution of the value of transactions on RASDAQ market

In terms of the number of companies traded on the RASDAQ market in 2013, the situation is presented as follows:

- category I: 4 companies;

- category II: 5 companies;

- category III: 973 company.

Currently, on the bond market of the BSE are traded 3 categories of bonds: corporate bonds, government bonds and municipal bonds.

At the end of 2013, on this market were carried out 3 issues of corporate bonds and were traded 28 issues of government bonds and 37 issues of municipal bonds.

The evolution of the value of transactions with bonds performed on the BSE in the period 2003 to 2013 is shown below:

Table 3 The evolution of the value of transactions with bonds on BSE

\begin{tabular}{|c|c|c|c|c|c|c|c|c|c|c|c|}
\hline Year & $\mathbf{2 0 0 3}$ & $\mathbf{2 0 0 4}$ & $\mathbf{2 0 0 5}$ & $\mathbf{2 0 0 6}$ & $\mathbf{2 0 0 7}$ & $\mathbf{2 0 0 8}$ & $\mathbf{2 0 0 9}$ & $\mathbf{2 0 1 0}$ & $\mathbf{2 0 1 1}$ & $\mathbf{2 0 1 2}$ & $\mathbf{2 0 1 3}$ \\
\hline $\begin{array}{c}\text { Transactions } \\
\text { value } \\
\text { (billion } \\
\text { Euros) }\end{array}$ & 5 & 71 & 35 & 282 & 233 & 62 & 303 & 620 & 128 & 321 & 314 \\
\hline
\end{tabular}




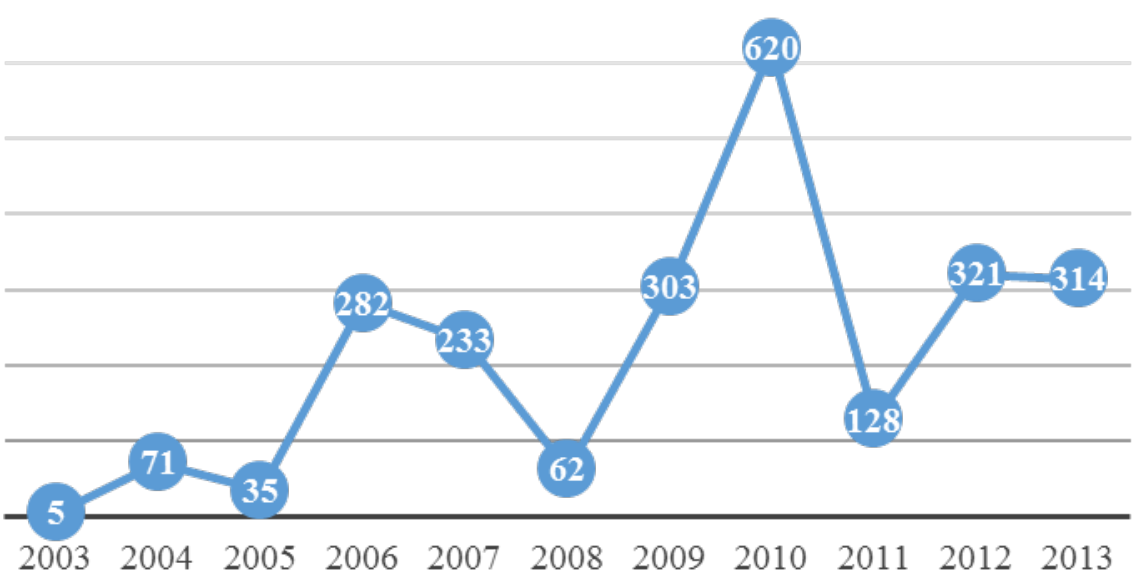

Figure 3 The evolution of the value of transactions with bonds on BSE

In Romania, the first derivatives stock exchange started operating in 2004 under the tutelage of the Monetary Financial and Commodities Exchange (from Sibiu). Currently, this stock exchange is called Sibex (Sibiu Stock Exchange). Derivatives stock exchange from BSE is a younger market being founded in 2009. This market is structured on several segments: futures market, options market and structured products market.

Derivatives market in Romania is still at beginning and has a great potential for development. If in 2010, on the structured products market of Bucharest Stock Exchange were recorded transactions in the value of 45,8 million RON, in 2013 the amount of such transactions has reached 531,6 million RON.

As regards capital market perspective in Romania we can say that the uncertainty about the evolution of the world economy and national economy, do not favor a significant increase in the short term of the stock market in Romania, but rather a stagnation.

As stated by Badea, L. (2012), the main objectives of the Bucharest Stock Exchange for the next period of time call into question the increase of liquidity in the market by attracting new investors,

However, in the longer term, with overcoming this crisis, it is estimated that the capital market in Romania will develop further and become increasingly more attractive for Romanian and foreign investors.

\section{Conclusions}

Even though the first stock exchange was established in 1881, the modern capital market in Romania is a relatively young market, which began to work with the reestablishment of Bucharest Stock Exchange in 1995.

The Romanian capital market has considerably grown in the last years. If the start was quite difficult, since 2001, the capital market has had an upward trend until the onset of economic and financial crisis in 2008.

In 2008, the stock market in Romania has experienced a strong rebound, the volume and number of transactions recorded in that year was well below the levels recorded 
in the years preceding the crisis. The return of capital market from the shock generated by the financial and economic crisis was slow and modest. Thus, if in 2007 the volume of shares transactions at BSE reached a record level of 4.2 billion Euros, in 2010, this volume decreased to the level of 1.2 billion Euros and by 2013 this volume had increased only up to the level of 2.5 billion Euros.

Statistical data presented in this paper, regarding the evolution of the capital market in Romania, put out the fact that this market was and is strongly linked to developments in the real economy, political and social events and military ones, that have produced both nationally and internationally.

As stated by Barna, F., and Mura, P. O. (2010), the financial development follows economic growth and the financial development is a cause of economic growth.

As regards capital market perspective in Romania we can say that in the short term we don't expect a major increase on that market. In the longer term it forecast a new increase of the capital market due to the increase of the foreign investor confidence in the Romanian economy.

\section{References}

Badea, L. (2012), Impact of the Financial Crisis on the Romanian Capital Market in the European Context, Theoretical and Applied Economics, Volume XIX, No. 3(568), pp. 27-40.

Bailey, R. (2005), The economics of financial markets, Cambridge University Press.

Barna, F., Mura, P. O. (2010), Capital market development and economic growth: the case of Romania, Annals of the University of Petroşani, Economics, Volume 10(2), pp. 31-42.

Datasets available at www.bvb.ro.

Datasets available at www.kmarket.ro.

Dragotă, V., Stoian, A., Pele, D.T., Mitrică, E., Bensafta, M. (2009), The development of the Romanian capital market: evidences on information efficiency, Romanian Journal of Economic Forecasting, Volume 2, pp. 147 160.

Drob, C. (2009) Investiţii directe de capital, Editura Alma Mater, Bacău.

Turcu, O., Mironescu, R., Drob, C., Feraru, A., et al (2008), Management, Editura Alma Mater, Bacău. 